\title{
Tolerance of Durum Wheat Cultivars to Postanthesis Drought Conditions as Affected by Seed Priming, Bio-Fertilizer and Potassium Application
}

\author{
Osman A. Al-Selhab ${ }^{1}$, Sami Sh. El-Tabbakh ${ }^{1}$, Ali I. Nawar ${ }^{1}$, Mosaad M. EL-Genbeehy ${ }^{1}$ \\ and Ahmed M. Shaalan ${ }^{2}$ \\ ${ }^{1}$ Crop Sci. Dept., Fac. Agriculture, Alexandria University. \\ ${ }^{2}$ Faculty of Desert and Environmental Agriculture, Matrouh Branch, Alexandria University. \\ Received on: 7/3/2016 \\ Accepted: $17 / 4 / 2016$
}

\begin{abstract}
The present study aimed to investigate the tolerance of different durum wheat (Triticum turgidum ssp. durum Desf. em. Musn) genotypes to drought stress at heading to maturity stage under the influence of drought alleviation treatments. The field work was carried out at Fuka Research Station, Faculty of Desert and Environmental Agriculture, Alexandria University, Matrouh Branch Egypt, in 2012/2013 and 2013/2014 winter seasons. The experimental design was split-plot, with four replicates where the main plots included six treatments as follows: 1) Spraying with potassium, 2) Priming with calcium chloride, 3) Bio-fertilization with HALEX $^{\circledR}$ 4) Seed hydro-priming, 5) Sowing of dry seed (these five treatments were subjected to drought by holding irrigation at postanthesis) and 6) Control (irrigation all season). The sub-plots included the three durum wheat genotypes. The results revealed insignificant variation for applied treatments on all studied characters, except for 100-grain weight, in the two seasons. Cultivars showed significant variations in LAI (at 80 DAS), dry weight of spikes (at $50 \%$ heading and 30 days later) and number of grains spike ${ }^{-1}$ in the two seasons. Interaction between drought alleviation treatments and cultivars was insignificant, for all studied characters in the two seasons. Also, wheat plants, irrigated all season, gave the highest 100 -grain weight $(5.31$ and $6.48 \mathrm{~g})$ in the two seasons, respectively. On the other hand, Sohag 3 was superior (0.23 and 0.25) to Marjawi (0.19 and 0.21) in LAI, in the two seasons, respectively. In addition, Beni Suef 5 gave the highest significant dry weight of spikes and number of grains spike ${ }^{-1}$ in the two seasons. Drought susceptibility index (DIS) values revealed that seed priming with $\mathrm{CaCl}_{2}$ and water tolerated drought at postanthesis stage and gave comparable grain yield to that of control. Beni Suef 5 and Marjawi showed higher tolerance to drought than Sohag 3.
\end{abstract}

Key words: Wheat, drought, seed priming, bio-fertilizer, potassium.

\section{INTRODUCTION}

Durum wheat (Triticum turgidum ssp durum Desf. em. Musn) is one of most grown crops under dry land conditions in the Mediterranean areas and is an important source of human nutrition. The need and importance of durum wheat are increasing due to increase in human population. Durum wheat represents $10 \%$ of the wheat grown globally, occupying about eleven million hectares in the Mediterranean areas (Karimizadeh et al., 2013). Drought stress is one of the most important factors, which affect the production of durum wheat in the arid and semi-arid areas because rainfall and temperatures, in such areas, show large and unpredictable fluctuations within and between growing seasons (Mir et al., 2012).

The drought stress can occur at any stage of growth. Most crop cultivars are susceptible to yield losses due to limited water supply during postanthesis period. The ability of a genotype to produce high yield, over a wide range of stress and non-stress environmental conditions, is essential for an ideal cultivar. Although drought may occur at any stage of durum wheat development in Mediterranean regions, climatic frequency studies have identified one major period when drought is most likely to occur and it is when the durum wheat is in the grain filling phase (Mohammadi et al., 2011).

To reduce the impact of drought on wheat, a variety of materials may by applied before or after sowing. El-Ashry et al. (2005) reported that the negative effect of drought on growth of wheat could be decreased by spraying potassium. Similarly, that potassium enhanced drought tolerance in plants by mitigating harmful effects through increasing translocation and by maintaining water balance. Osmotic adjustment has been considered an important phenomenon for mitigating the adverse effects of drought stress in plants (Ashraf, 2010). For that, certain organic (proline, soluble sugars, glycine betaine, proline betaine) and inorganic (potassium ions) compatible solutes are accumulated in the plant cells (Zhang et al., 2009 and Baysal-Furtana et al., 2013). Among these compatible solutes, potassium was very effective in the regulation of plants homeostasis under drought stress. Moreover, potassium uptake and accumulation is increased during drought and plays a major role in stomata opening and closing, 
transpiration, photosynthesis, protective protein synthesis, and osmoregulation of plant cells (Raza et al., 2012 and 2013). Potassium also is accumulated in plants to regulate osmotic adjustment under drought or osmotic stress.

In sustainable agriculture system, biological fertilizers play an important role in crop production and increasing soil fertility conservation (Sharma et al. 2010). Bio-fertilizers are products containing living cells of different types of microorganisms (Chen, 2006) that have an ability to convert nutritionally important elements from unavailable to available form through bio-logical processes and are known to help with expansion of the root system and increase seed germination rate, Behrooz et al. (2015) reported that bio-fertilizer had an effective function in improving plant growth characteristics and increasing of products quality of wheat cultivars under dryland conditions.

Seed priming is a pre-sowing strategy for influencing seedling development by modulating pre-germination metabolic activity prior to emergence of the radicle and, generally, enhances germination rate and plant performance (Taylor and Harman, 1990). Priming may increase these factors which can increase crop tolerance to drought and salinity (Wang and Shen, 1991, and Aslam et al., 2013). Calcium plays a vital role in plant response to drought stress. Calcium is of great significance in many plant physiological functioning and responses to abiotic stresses. It acts as a signal transmitter to help in the regulation of plant growth and development under stress. Most importantly, it regulates the opening and closing of stomata and adaptation of plant to drought through ABA homeostasis (Song et al., 2008). In wheat, Ca has been reported to decrease the devastating impact of drought by increasing the concentration of compatible solutes (glycine betaine and proline), which help in the amelioration of stress in the growth of seedlings, improve plant water status and reduce membrane injury (Nayyar, 2003). Various pre-hydration or priming treatments have been employed to increase the speed and synchrony of seed germination. Common priming techniques include osmopriming (soaking seeds in osmotic solutions) such as calcium chloride. Sharma et al., (2010) found that pre-sowing hydration (seed priming) of seed with 3\% calcium chloride and 15 ppm gibberellic acid increased emergence count, as compared to the other applied treatments.

The main objective of the present study was to investigate the tolerance of different durum wheat (Triticum turgidum ssp durum Desf. em. Musn) genotypes to drought stress at heading to maturity stage under the influence of seed priming with water and calcium chloride, application of HALEX ${ }^{\circledR}$ biofertilizer and spraying with potassium, as methods for increasing wheat plant tolerance to drought stress.

\section{MATERIALS AND METHODS}

Wheat experiments were carried out in the Agricultural Research Station, Alexandria University at Faculty of Desert and Environmental Agriculture (Fuka), Matrouh Branch, located at North West Coast of Egypt $\left(\mathrm{N}=31^{\circ}\right.$ 04., $\left.\mathrm{E}=27^{\circ} 54\right)$ during the two winter growing seasons of $2012 / 2013$ and 2013/2014. The main objective of the present study was to investigate the tolerance of different durum (Triticum turgidum ssp durum Desf. em. Musn) wheat genotypes, one Libyan variety (Marjawi) and two Egyptian cultivars (Beni Suef 5 and Sohag 3), to drought stress at heading to maturity stages (postanthesis) under the influence of seed priming (with distilled water hydropriming) and calcium chloride (osmopriming), HALEX ${ }^{\circledR}$ (bio-fertilizer) and spraying with potassium, as methods for increasing wheat plant tolerance to drought stress. The experimental site soil had the following properties: Texture $=$ sandy (calcareous), $\mathrm{pH}=8.3$, total organic matter $=0.68 \%$, and $\mathrm{Ec}=3.4$ $\mathrm{dS} / \mathrm{m}$ as an average of the two seasons.

The experimental design, used in the two seasons, was split-plot in randomized complete block design (RCBD) with four replications. The main plots included six treatments. i.e 1) Spraying twice with potassium (as liquid, $\mathrm{K}_{2} \mathrm{O}=36.5 \%$ ) at the rate of $2.38 \mathrm{~L} / 476 \mathrm{~L}$ water/ha after thirty days from sowing (DAS) and the second after sixty DAS, 2) Priming with calcium chloride, where grains were soaked for twelve hours, prior to sowing, in a 5:1 solution of $5 \mathrm{mg} / 1$ of $\mathrm{CaCl}_{2}, 3$ ) Bio-fertilization with HALEX $^{\circledR}$, (containing a mixture of growthpromoting N-fixing bacteria of Azotobacteriaceae, Azospirillum and Klebsiella) at the rate of 1.20 $\mathrm{kg} / \mathrm{ha}$, where wheat grains were mixed well with the biofertilzer directly before sowing, 4) Hydropriming: soaking in distilled water for twelve hours prior to sowing, 5) Sowing of dry seed directly and 6) Control. The first five treatments were subjected to withholding irrigation at early heading, while the control was irrigated throughout the season to fulfill the requirements of durum wheat under the experimental site conditions. While, the sub- plots included the three durum wheat genotypes. Sub-plot size, in both seasons, was $6 \mathrm{~m}^{2}$ (3m long $* 2 \mathrm{~m}$ wide) and included ten rows at row spacing of $0.3 \mathrm{~m}$. Sowing date was November $27^{\text {th }}$ in the two seasons. Wheat cultivars were sown at the rate of $95.2 \mathrm{Kg} / \mathrm{ha}$. Phosphorus fertilizer, as calcium monophosphate $\left(15.50 \% \mathrm{P}_{2} \mathrm{O}_{5}\right)$ was added during land preparation at the rate of $37.0 \mathrm{~kg} \mathrm{P}_{2} \mathrm{O}_{5} / \mathrm{ha}$. Nitrogen fertilizer was applied at the rate of 142.8 $\mathrm{kg} \mathrm{N} / \mathrm{ha}$ in the form of ammonium nitrate $(33.5 \%$ $\mathrm{N}$ ), in three doses; i.e., $1 / 5$ at sowing, $2 / 5$ at tillering stage and $2 / 5$ at booting stage. Irrigation was applied, using sprinkler irrigation system. 


\section{Measured characters:}

To monitor the effect of drought on wheat growth, and the effect of applied treatments to overcome the damaging effects of drought on plant growth, the following characters were measured from random samples taken at designated periods for each character:

1. Plant dry weight (g), at 30 and 60 days after sowing.

2. Leaf area index $(\mathrm{LAI})=(\mathrm{LA} 2+\mathrm{LA} 1) / 2^{*}$ (1/ground area), at 40 and 80 days after sowing (DAS), according to Gardner et al. (1985)

3. Dry weight of spikes (g), at $50 \%$ heading and 30 days later.

At harvest, the followings traits were measured:

4. Spike length $(\mathrm{cm})$ : as an average of five random spikes/sub-plot.

5. Number of grains/spike: as an average of five random spikes/sub-plot.

6. 100-grain weight (g): as an average of three 100grain samples/sub-plot.

7. Grain yield ( $t / h a)$ : calculated by converting the grain yield obtained from the inner six rows of each sub-plot to t/ha.

8. Harvest index (H.I \%): was computed, using the following equation:

H.I \% $=$ Grain yield/ Biological yield $* 100$

9. Grain protein content (\%): The protein content of the whole grains was determined, according to the Kjeldahl method (A.O.A.C, 1980) applying a factor of $\mathrm{N} \times 5.7$.

10. Drought susceptibility index (DSI), according to Fischer and Maurer (1978), as follows:

DSI $=1-\frac{\mathrm{Y}_{\mathrm{s}}}{\mathrm{Y}_{\mathrm{w}}} / 1-\frac{\hat{\mathrm{Y}}_{\mathrm{s}}}{\hat{\mathrm{Y}}_{\mathrm{w}}}$

Where,

Ys: Yield under stress condition.

Yw: Yield under all season irrigation.

$\bar{Y}_{S}$ : Mean of genotypes or treatment under stress condition.

$\bar{Y}_{\mathrm{w}}$ : Mean of genotypes or treatment under all season irrigation.

$\left(1-\frac{\widehat{\mathrm{Y}}_{\mathrm{s}}}{\widehat{\mathrm{Y}}_{\mathrm{w}}}\right)=$ Environmental stress intensity.

Data were subjected to the proper analysis according to Gomez and Gomez (1984) using SAS (Statistical Analyses Systems) ver. 9.1 (2000). Means were compared, using the least significant difference (LSD) value at $5 \%$ level of probability.

RESULTS AND DISCUSSION

Analysis of variance (Table 1) indicates that applied treatments, to overcome the damaging effect of drought on plant growth, were insignificantly different, in the two sampling dates and the two seasons for plant dry weight, LAI and dry weight of spikes. Cultivars showed significant variation in LAI at 60 DAS in the two seasons and dry weight of spikes at $50 \%$ heading and thirty days later in the two seasons. Interaction was insignificant between drought alleviation treatments and cultivars, for all studied characters in the two seasons. That implies a similar behavior for cultivars, as influenced by the applied treatments. Means, presented in Table (2), showed that, though insignificant, in early stages of growth, hydropriming showed higher plant dry weight and LAI, compared to the faster germination and emergence of seedlings, due to imbibing of water and activation of pre-germination processes. Taylor and Harmen (1990) reported that seed priming modulated pre-germination activity prior to emergence of radical and enhanced germination rate and plant performance. Similarly, Kamyar and Hamdollah (2012) concluded that hydropriming improved seed germination under drought salt conditions. Concerning dry weight of spikes, drought alleviation treatments, especially seed priming with water or $\mathrm{CaCl}_{2}$, and application of biofertilizer, gave comparable values to all season irrigation (control) in the two sampling dates and the two seasons. That implies a beneficial effect for those treatments in overcoming the damaging effect of drought on spike growth and grain development, especially at the later stage (second sample taken after thirty days from $50 \%$ heading). Similar findings were reported by Attia et al. (2005) for biofertilizer effects and Siddiqui et al. (2011) for osmopriming with $\mathrm{CaCl}_{2}$, concluding that both biological fertilizers and calcium played an important role in meliorating the adverse effects of drought on wheat plants.

The results in Table (3) showed that Sohag 3 was superior to Marjawi in LAI, in the second sample, in the two seasons, but was similar to Beni Suef 5. That may be attributed to the genetic constitution differences between cultivars. On the other hand, Beni Suef 5 was significantly superior to Marjawi and Sohag 3 in dry weight of spikes in the two sampling dates in the two seasons. That may indicate the higher tolerance, to imposed drought, of Beni suef 5, compared to the two other genotypes at postanthesis stage, resulting in higher accumulation of dry matter in the spike and higher dry weight of spikes. Similar findings were repoted by Keyvan (2010) and Khayatnezhad et al. (2011) who found variation between and within groups of bread and durum wheat genotypes for drought tolerance, depending on the studied characters. Similarly, Bowne et al. (2012) reported differences between three wheat cultivars in their tolerance to drought at terminal stages of growth.

Concerning grain yield components; i.e., number of spikes $\mathrm{m}^{-2}$, number of grains spike ${ }^{-1}$ and 100 -grain weight, analysis of variance in (Table 4) revealed that the applied treatments had a significant effect on 100-grain weight in the two seasons. 


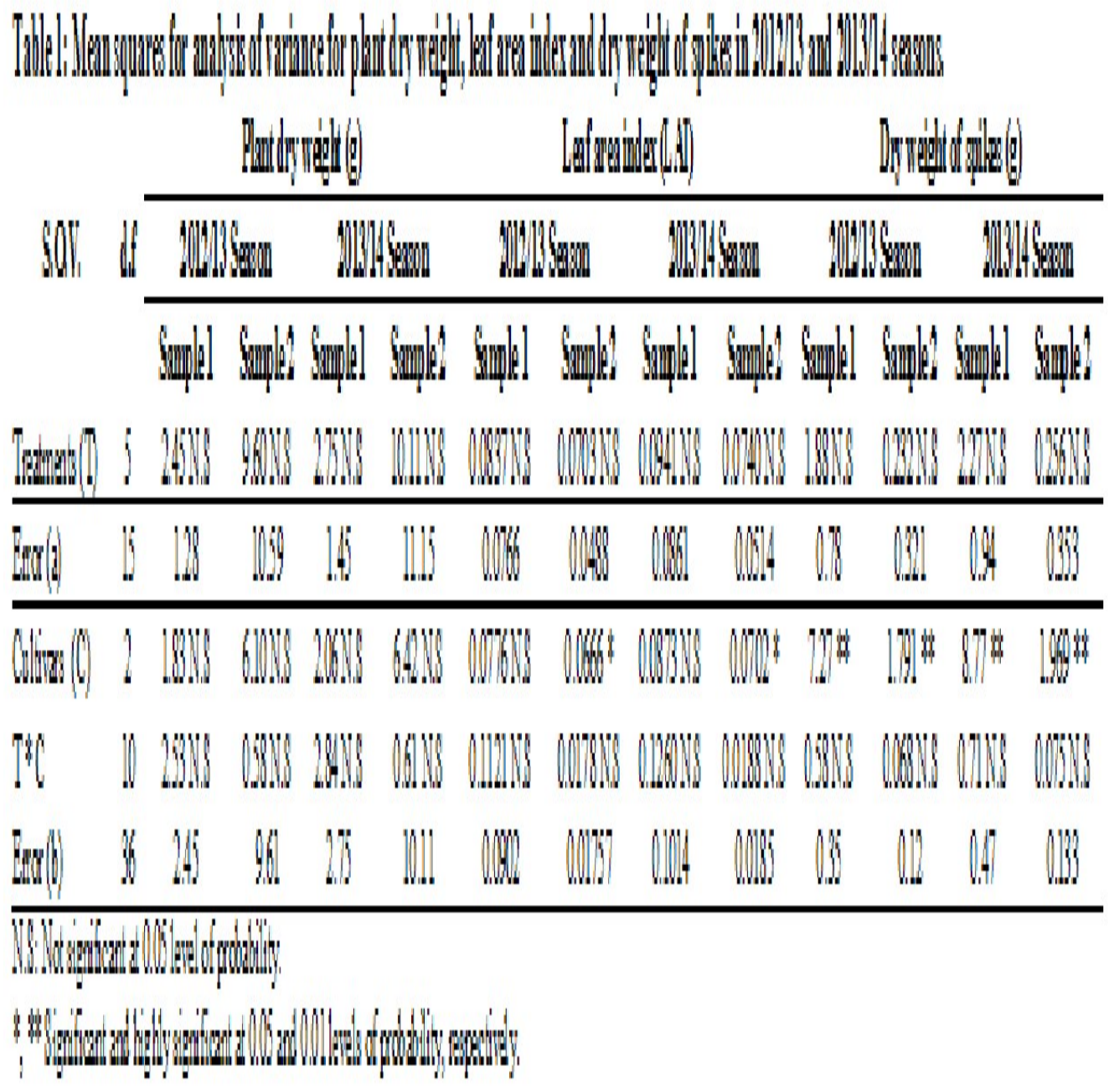




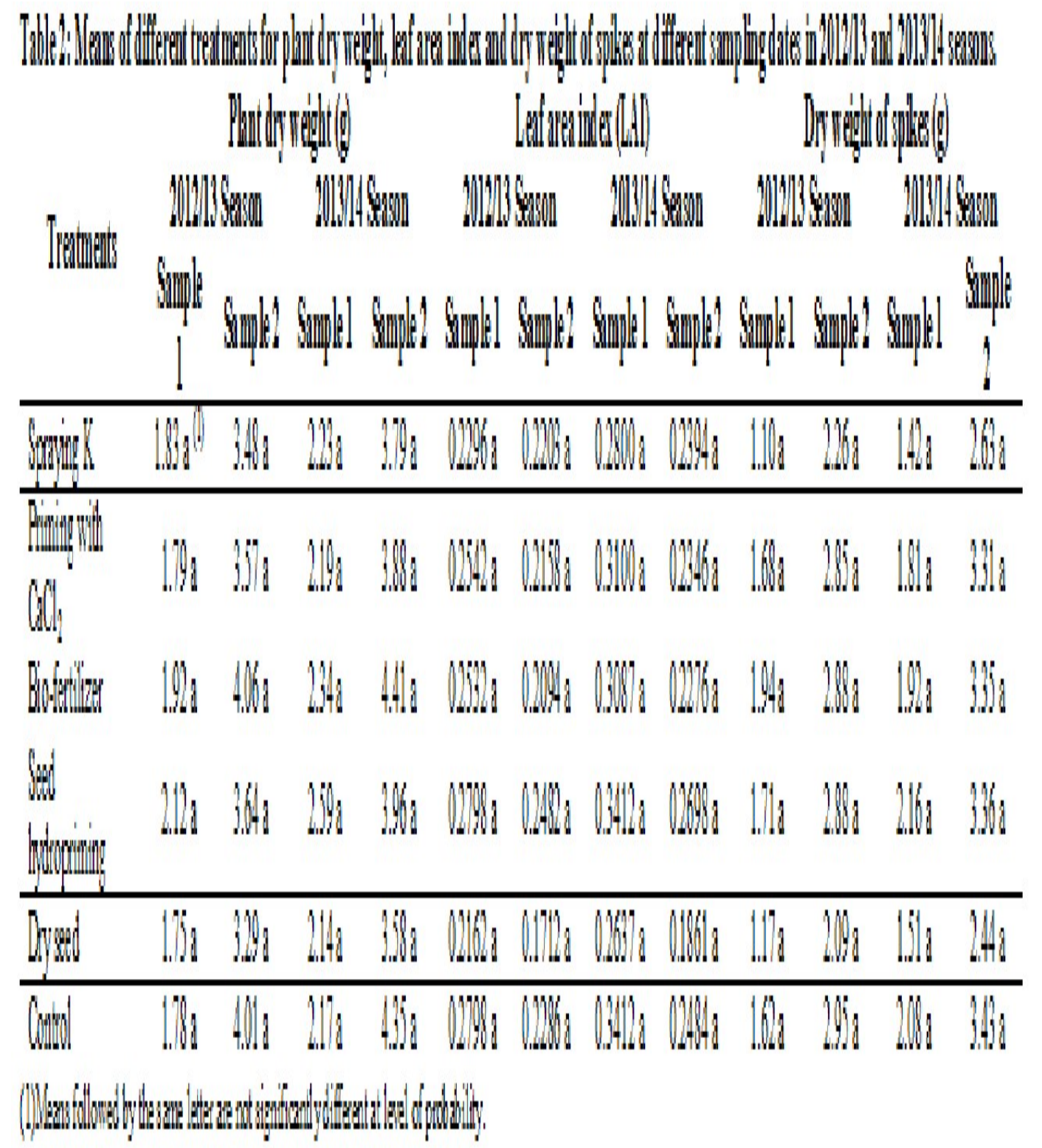




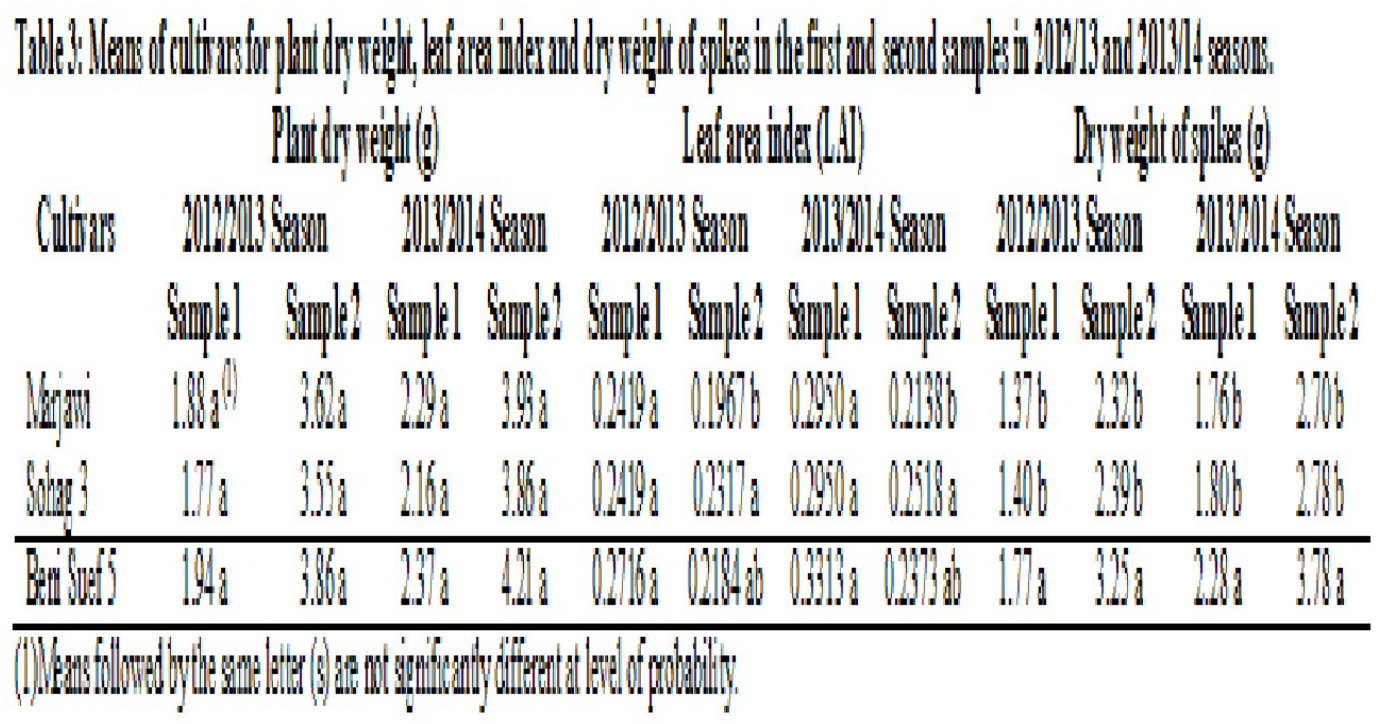

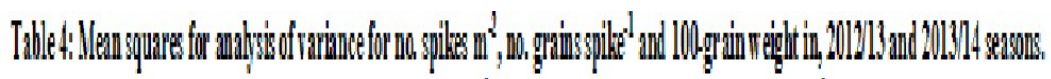

\begin{tabular}{|c|c|c|c|c|c|c|c|}
\hline \multirow{2}{*}{ SOS } & \multirow{2}{*}{$d$} & \multicolumn{2}{|c|}{ 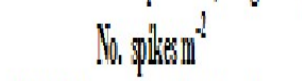 } & \multicolumn{2}{|c|}{ 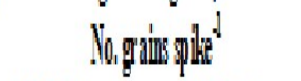 } & \multicolumn{2}{|c|}{ 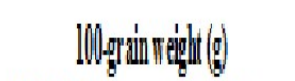 } \\
\hline & & 20101/19xin & 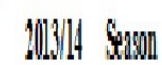 & 201113 Sxwa & MIII) Shan & 2013) 6xing & 101/HSWon \\
\hline Traments(?) & j & 295aA4s & billijiss & $100130 \mathrm{NS}$ & 1726618 & $4.5)^{8}$ & $500^{*}$ \\
\hline $\operatorname{Errog}(\mathrm{l})$ & 15 & 4,686 & 497.18 & 63212 & 7623 & 1.18 & 1.37 \\
\hline Citrans (Q) & ? & 2426018 & 2775518 & 12128 & $1: 10$ 降 & $1.07 \mathrm{NS}$ & $124 \mathrm{NS}$ \\
\hline$I^{y} \mathrm{C}$ & II & Ma6ris & 3998018 & 4h:J1:S & 36915 & 06328 & 02218 \\
\hline$\overline{E r r o(b)}$ & 36 & 191490 & 2010.14 & 30.66 & 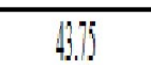 & 0.99 & 0.7 \\
\hline
\end{tabular}


Table 5: Means of different treatments for no. spikes $\mathrm{m}^{-2}$, no. grains spike $^{-1}$ and 100 -grain weight in 2012/13 and 2013/14 seasons.

\begin{tabular}{lcllllc}
\hline \multirow{2}{*}{ Treatments } & \multicolumn{2}{c}{ No. ${\text { spikes } \mathbf{~ m}^{-2}}^{2}$} & \multicolumn{2}{c}{ No. grains spike } & \multicolumn{2}{c}{ 100-grain weight (g) } \\
\cline { 2 - 7 } & $\begin{array}{l}\mathbf{2 0 1 2 / 1 3} \\
\text { Season }\end{array}$ & $\begin{array}{l}\mathbf{2 0 1 3 / 1 4} \\
\text { Season }\end{array}$ & $\begin{array}{l}\mathbf{2 0 1 2 / 1 3} \\
\text { Season }\end{array}$ & $\begin{array}{l}\mathbf{2 0 1 3 / 1 4} \\
\text { Season }\end{array}$ & $\begin{array}{l}\mathbf{2 0 1 2 / 1 3} \\
\text { Season }\end{array}$ & $\begin{array}{l}\mathbf{2 0 1 3 / 1 4} \\
\text { Season }\end{array}$ \\
\hline Spraying $\mathrm{K}$ & $169.74 \mathrm{a}{ }^{(1)}$ & $207.00 \mathrm{a}$ & $35.87 \mathrm{a}$ & $43.75 \mathrm{a}$ & $3.88 \mathrm{~cd}$ & $4.74 \mathrm{c}$ \\
\hline Priming with $\mathrm{CaCl}_{2}$ & $156.01 \mathrm{a}$ & $190.25 \mathrm{a}$ & $37.72 \mathrm{a}$ & $46.00 \mathrm{a}$ & $4.79 \mathrm{abc}$ & $5.85 \mathrm{ab}$ \\
\hline Bio-fertilizer & $161.40 \mathrm{a}$ & $196.83 \mathrm{a}$ & $39.97 \mathrm{a}$ & $48.75 \mathrm{a}$ & $4.70 \mathrm{abc}$ & $5.74 \mathrm{ab}$ \\
\hline Seed hydropriming & $161.06 \mathrm{a}$ & $196.42 \mathrm{a}$ & $40.51 \mathrm{a}$ & $49.41 \mathrm{a}$ & $5.20 \mathrm{ab}$ & $6.35 \mathrm{ab}$ \\
\hline Dry seed & $134.68 \mathrm{a}$ & $164.25 \mathrm{a}$ & $34.50 \mathrm{a}$ & $42.08 \mathrm{a}$ & $3.68 \mathrm{bd}$ & $4.37 \mathrm{c}$ \\
\hline Control & $159.55 \mathrm{a}$ & $194.58 \mathrm{a}$ & $42.84 \mathrm{a}$ & $52.25 \mathrm{a}$ & $5.31 \mathrm{a}$ & 6.48 \\
\hline
\end{tabular}

(1) Means followed by the same letter (s) are not significantly different at 0.05 level.

Table 6: Means of cultivars for no. spikes $\mathrm{m}^{-2}$, no. grains spike ${ }^{-1}$ and 100-grain weight in 2012/13 and 2013/14 seasons.

\begin{tabular}{llllllc}
\hline \multirow{3}{*}{ Cultivars } & \multicolumn{2}{c}{ No. spikes. $\mathbf{~ m}^{-2}$} & \multicolumn{2}{c}{ No. grains. spike } & \multicolumn{2}{c}{ 100-grain weight (g) } \\
\cline { 2 - 7 } & $\begin{array}{l}\mathbf{2 0 1 2 / 1 3} \\
\text { Season }\end{array}$ & $\begin{array}{l}\mathbf{2 0 1 3 / 1 4} \\
\text { Season }\end{array}$ & $\begin{array}{l}\mathbf{2 0 1 2 / 1 3} \\
\text { Season }\end{array}$ & $\begin{array}{l}\mathbf{2 0 1 3 / 1 4} \\
\text { Season }\end{array}$ & $\begin{array}{l}\mathbf{2 0 1 2 / 1 3} \\
\text { Season }\end{array}$ & $\begin{array}{l}\mathbf{2 0 1 3 / 1 4} \\
\text { Season }\end{array}$ \\
\hline Marjawi & $147.43 \mathrm{a}^{(1)}$ & $179.8 \mathrm{a}$ & $37.20 \mathrm{~b}$ & $45.37 \mathrm{~b}$ & $4.93 \mathrm{a}$ & $6.02 \mathrm{a}$ \\
\hline Sohag 3 & $160.17 \mathrm{a}$ & $195.33 \mathrm{a}$ & $33.10 \mathrm{c}$ & $40.37 \mathrm{c}$ & $4.60 \mathrm{a}$ & $5.62 \mathrm{a}$ \\
\hline Beni Suef 5 & $163.59 \mathrm{a}$ & $199.50 \mathrm{a}$ & $45.40 \mathrm{a}$ & $55.37 \mathrm{a}$ & $4.60 \mathrm{a}$ & $5.62 \mathrm{a}$ \\
\hline
\end{tabular}

(1) Means followed by the same letter (s) are not significantly different at 0.05 level.

Table 7: Mean squares for analysis of variance for grain yield, harvest index and protein percentage in 2012/ 13 and 2013/14 seasons.

\begin{tabular}{|c|c|c|c|c|c|c|c|}
\hline \multirow[b]{2}{*}{ S.O.V. } & \multirow[b]{2}{*}{ d.f } & \multicolumn{2}{|c|}{ Grain yield (ton $\mathrm{ha}^{-1}$ ) } & \multicolumn{2}{|c|}{ Harvest index } & \multicolumn{2}{|c|}{ Protein (\%) } \\
\hline & & $\begin{array}{l}\text { 2012/13 } \\
\text { Season }\end{array}$ & $\begin{array}{l}2013 / 14 \\
\text { Season } \\
\end{array}$ & $\begin{array}{l}\text { 2012/13 } \\
\text { Season }\end{array}$ & $\begin{array}{l}\text { 2013/14 } \\
\text { Season }\end{array}$ & $\begin{array}{l}\text { 2012/13 } \\
\text { Season }\end{array}$ & $\begin{array}{l}2013 / 14 \\
\text { Season }\end{array}$ \\
\hline Treatments $(\mathrm{T})$ & 5 & $0.281 \mathrm{~N} . \mathrm{S}$ & 0.348 N.S & $12.36 \mathrm{~N} . \mathrm{S}$ & 15.27 N.S & 0.569 N.S & 2.695 N.S \\
\hline Error (a) & 15 & 0.102 & 0.127 & 9.08 & 11.21 & 2.159 & 3.519 \\
\hline Cultivars (C) & 2 & 0.028 N.S & $0.035 \mathrm{~N} . \mathrm{S}$ & 3.87 N.S & 4.788 N.S & 2.177 N.S & $4.281 \mathrm{~N} . \mathrm{S}$ \\
\hline $\mathrm{T} * \mathrm{C}$ & 10 & 0.036 N.S & 0.045 N.S & 10.54 N.S & $13.01 \mathrm{~N} . \mathrm{S}$ & $1.751 \mathrm{~N} . \mathrm{S}$ & 3.656 N.S \\
\hline Error (b) & 36 & 0.025 & 0.031 & 7.38 & 9.12 & 2.023 & 2.771 \\
\hline
\end{tabular}

N.S: Not significant at 0.05 level of probability.

Table 8: Means of different treatments for grain yield, harvest index, drought susceptibility index and protein percentage in $2012 / 13$ and $2013 / 14$ seasons.

\begin{tabular}{lcccccccc}
\hline & \multicolumn{2}{c}{$\begin{array}{c}\text { Grain yield } \\
\text { (ton } \mathbf{h a}^{-\mathbf{1}} \text { ) }\end{array}$} & \multicolumn{2}{c}{ Harvest index $(\mathbf{H I})$} & \multicolumn{2}{c}{$\begin{array}{c}\text { Drought } \\
\text { Susceptibility index }\end{array}$} & \multicolumn{2}{c}{ Protein (\%) } \\
\cline { 2 - 11 } & $\begin{array}{l}\mathbf{2 0 1 2 / 1 3} \\
\text { Season }\end{array}$ & $\begin{array}{l}\mathbf{2 0 1 3} / \mathbf{1 4} \\
\text { Season }\end{array}$ & $\begin{array}{l}\mathbf{2 0 1 2 / 1 3} \\
\text { Season }\end{array}$ & $\begin{array}{l}\mathbf{2 0 1 3 / 1 4} \\
\text { Season }\end{array}$ & $\begin{array}{l}\mathbf{2 0 1 2} / \mathbf{1 3} \\
\text { Season }\end{array}$ & $\begin{array}{l}\mathbf{2 0 1 3} / \mathbf{1 4} \\
\text { Season }\end{array}$ & $\begin{array}{l}\mathbf{2 0 1 2} / \mathbf{1 3} \\
\text { Season }\end{array}$ & $\begin{array}{l}\mathbf{2 0 1 3} / \mathbf{1 4} \\
\text { Season }\end{array}$ \\
\hline Spraying K & $0.41 \mathrm{a}^{(1)}$ & $0.54 \mathrm{a}$ & $11.14 \mathrm{a}$ & $14.67 \mathrm{a}$ & 1.576 & 1.625 & $12.00 \mathrm{a}$ & $12.51 \mathrm{a}$ \\
\hline $\begin{array}{l}\text { Priming with } \\
\mathrm{CaCl}_{2}\end{array}$ & $0.59 \mathrm{a}$ & $0.78 \mathrm{a}$ & $12.11 \mathrm{a}$ & $15.94 \mathrm{a}$ & 0.591 & 0.598 & $11.96 \mathrm{a}$ & $12.77 \mathrm{a}$ \\
\hline Bio-fertilizer & $0.53 \mathrm{a}$ & $0.71 \mathrm{a}$ & $12.27 \mathrm{a}$ & $16.15 \mathrm{a}$ & 0.923 & 0.897 & $12.37 \mathrm{a}$ & $13.38 \mathrm{a}$ \\
\hline $\begin{array}{l}\text { Seed } \\
\text { hydropriming }\end{array}$ & $0.66 \mathrm{a}$ & $0.88 \mathrm{a}$ & $12.44 \mathrm{a}$ & $16.37 \mathrm{a}$ & 0.214 & 0.171 & $12.42 \mathrm{a}$ & $13.45 \mathrm{a}$ \\
\hline Dry seed & $0.39 \mathrm{a}$ & $0.52 \mathrm{a}$ & $12.57 \mathrm{a}$ & $16.55 \mathrm{a}$ & 1.687 & 1.711 & $12.44 \mathrm{a}$ & $13.54 \mathrm{a}$ \\
\hline Control & $0.69 \mathrm{a}$ & $0.92 \mathrm{a}$ & $13.80 \mathrm{a}$ & $18.17 \mathrm{a}$ & - & - & $12.13 \mathrm{a}$ & $13.11 \mathrm{a}$ \\
\hline
\end{tabular}

(1) Means followed by the same letter are not significantly different at 0.05 level.

Table 9: Means of cultivars for grain yield, harvest index, drought susceptibility index and protein percentage in $2012 / 13$ and $2013 / 14$ seasons.

\begin{tabular}{|c|c|c|c|c|c|c|c|c|}
\hline \multirow{2}{*}{ Cultivars } & \multicolumn{2}{|c|}{$\begin{array}{l}\text { Grain yield } \\
\left(\text { ton } \mathrm{ha}^{-1}\right)\end{array}$} & \multicolumn{2}{|c|}{ Harvest index } & \multicolumn{2}{|c|}{$\begin{array}{c}\text { Drought } \\
\text { susceptibility index }\end{array}$} & \multicolumn{2}{|c|}{ Protein (\%) } \\
\hline & $\begin{array}{l}\text { 2012/13 } \\
\text { Season }\end{array}$ & $\begin{array}{l}2013 / 14 \\
\text { Season }\end{array}$ & $\begin{array}{l}2012 / 13 \\
\text { Season }\end{array}$ & $\begin{array}{l}2013 / 14 \\
\text { Season }\end{array}$ & $\begin{array}{l}\text { 2012/13 } \\
\text { Season }\end{array}$ & $\begin{array}{l}2013 / 14 \\
\text { Season }\end{array}$ & $\begin{array}{l}\text { 2012/13 } \\
\text { Season }\end{array}$ & $\begin{array}{l}2013 / 14 \\
\text { Season }\end{array}$ \\
\hline Marjawi & $0.52 \mathrm{a}^{(1)}$ & $0.69 \mathrm{a}$ & $12.01 \mathrm{a}$ & $15.81 \mathrm{a}$ & 0.902 & 0.89 & $12.73 \mathrm{a}$ & $13.44 \mathrm{a}$ \\
\hline Sohag 3 & $0.55 \mathrm{a}$ & $0.73 a$ & $12.68 \mathrm{a}$ & $16.69 \mathrm{a}$ & 1.272 & 1.32 & $11.70 \mathrm{a}$ & $12.83 \mathrm{a}$ \\
\hline Beni Suef 5 & $0.58 \mathrm{a}$ & $0.76 \mathrm{a}$ & $12.47 \mathrm{a}$ & $16.41 \mathrm{a}$ & 0.734 & 0.75 & $12.23 \mathrm{a}$ & $13.11 \mathrm{a}$ \\
\hline
\end{tabular}

(1) Means followed by the same letter are not significantly different at 0.05 level. 

Cultivars had significant effect on number of grains spike $^{-1}$ in the two seasons. The interaction was insignificant between treatments and cultivars for all studied characters in both seasons. Means of the number of spikes $\mathrm{m}^{-2}$ and number of grains spike $\mathrm{s}^{-1}$ (Table 5) showed that such traits were insignificantly different in the two seasons. This may be due to the complete (full) establishment before the impact of the drought, which was imposed at 50\% heading. However, it was noted that spraying with potassium, at vegetative stage, increased number of spikes $\mathrm{m}^{-2}$, compared to the other treatments and control in the two seasons. That may be attributed to the role of potassium in overcoming drought effects in all critical stages of growth through osmoregulation and improving plant growth (Aowne et al, 2012). On the other hand, seed hydropriming showed a relatively higher number of grains spike ${ }^{-1}$, compared to the other treatments and control (Table 5). That may be due to the early establishment of hydroprimed seedlings, leading to early flowering and, thus, escaping the damaging effects of drought on grain formation and development. Similar findings were reported by Garg (2010). Regarding 100-grain weight, wheat plants, irrigated all season, gave the highest values for that character. However, seed priming with calcium chloride, water and bio-fertilization with HALEX $^{\circledR}$ gave statistically similar values to control in the two seasons. That may be attributed to the effect of those treatments in overcoming the drought stress at grain filling stage. On the other hand, spraying potassium gave significantly lower 100grain weight and was comparable to dry seed treatment. That may be attributed to the potassium role in stomatal closure under drought stress conditions, leading to lower photosynthesis activity and translocation of photosynthates to individual grains, compared to the other treatments. These findings were in accordance with those reported by Nayyar (2003) and Siddiqui et al. (2011) for priming with $\mathrm{CaCl}_{2}$, Garg (2010) for hydropriming and Bassel et al, (2001) for bio-fertilization.

Results presented in Table (6) indicated that the three studied cultivars had similar values for number of spikes $\mathrm{m}^{-2}$ and 100-grain weight. However, Beni Suef 5 had a significantly higher number of grains spike $^{-1}$, followed by Marjawi, whereas Sohag 3 gave the significantly lowest number of grains spike ${ }^{-1}$ in the two seasons. These differences among cultivars may be related to their tolerance to drought conditions, which were controlled by the genetic constitution of the genotype. Smith and Griffiths (1993) reported natural genetic variation in traits related to drought tolerance in durum wheat. In addition, Abdullah et al. (2011) reported variation in drought tolerance of Syrian durum wheat genotypes and concluded that tolerant genotypes suffered less reduction in grain yield components compared to sensitive genotypes.

Analysis of variance in (Table 7) indicated insignificant variations in grain yield $\mathrm{ha}^{-1}$, harvest index and protein content, as influenced by the applied treatments, cultivars, and their interaction. However, in both seasons, data in (Table 8) revealed that priming with $\mathrm{CaCl}_{2}$ and hydropriming gave a comparable grain yield to the control. Drought susceptibility index (DSI) values revealed that these two treatments suffered less damage from imposed drought at pre-anthesis growth stage, compared to the other applied treatments. Untreated dry seed and spraying with potassium gave high values for DSI, indicating the low tolerance of wheat plants to drought stress. These findings may elucidate the role of seed priming, either osmopriming with $\mathrm{CaCl}_{2}$ or hydropriming, in overcoming the damaging effects of drought through regulation of several biological processes in wheat plants, such as osmoregulation, photosynthesis, stomatal closure, etc. in accordance with the findings reported by Nayyar (2003), Sharma et al. (2010) and Aslam et al. (2013).

The findings, reported in the present investigation, revealed the possibility of alleviating the damaging effects of drought, occurring at grains formation and development stage in durum wheat through hydropriming, which enhances plants establishment early in the season, thus, they may escape, or tolerate, terminal drought conditions. However, bio-fertilization and osmopriming, with calcium chloride enhance vegetative growth in early stages, combined with regulation of biological processes, such as photosynthesis and transpiration, which increases the wheat plant tolerance, to drought conditions. The results, also, indicated the importance of growing the suitable cultivar which has a genetic ability to tolerate drought.

\section{REFERENCES}

A.O.A.C. (1980). Association of Official Analytical Chemists. Official Methods of Analysis. $\mathbf{1 3}^{\text {rd }}$ ed. Washington, U.S.A.

Abdullah, F., F. Hareri, M. Naaesan, A.A. Ammar and O. ZuherKanbar. (2011). Effect of drought on different physiological characters and yield component in different varieties of Syrian durum wheat. J. Agric. Sci. 3 (3):127-133.

Aowne, M., Raza, S., Saleem, M.F. , S.A., Khaliq and M.A. Wahid. (2012). Foliar application of potassium under water deficit conditions improved the growth and yield of wheat (Triticum aestivum L.). The Journal of Animal \& Plant Sciences 22 (2): 2012, Page: 431-437.

Ashraf, M. (2010). Inducing drought tolerance in plants: Some recent advances. Biotech. Adv. 28:169- 183 . 
Aslam, M., M. S. I. Zamir, I. Afzal, M. Yaseen, M. Mubeen and A. Shoaib. (2013). Drought stress, its effect on maize production and development of drought tolerance through potassium application. Cerce Aări Agronomice în Moldova XLVI: 99-114.

Attia, M. A., M. A. Ashub and M.O. Salem. (2005). Effect of strip water harvesting system and fertilizer recommended pagkage on wheat under rainfed condition at West Matrouh Res. Bull.1-14 Ain ShamsUniv.

Bassel, S.A.A., E.M. Ibrahim and M.M.A. Bader. (2001). Effect of preceding summer crops, nitrogen fertilizer rates and bio-fertilizer on wheat crop productivity. Al-Azhar J. Agric. Res. (34): 85-98.

Baysal-Furtana, G., H.Duman and R.Tipirdamaz. (2013). Seasonal changes of inorganic and organic osmolytes content in thre endemic Limonium species of Lake Tuz (Turkey). Turkish J. Bot. 37:455-463.

Behrooz, A., M.R. Ardakan, F. Paknejad and F. Rejali. (2015). Effect of Mycorrhiza and Azotobacter on concentration of macroelements and root colonization percentage in different cultivars of wheat (Triticum aestivum L.). Biological Forum-An International Journal 7(2): 895-900.

Bowne, J.B., T. A. Erwin, J. Juttner, T. Schnurbusch, P. Langridge, A. Bacic and U. Roessner. (2012). Drought responses of leaf tissues from wheat cultivars of differing drought tolerance at the metabolite level. Molecular Plant 5 (5): 418-429.

Chen, J. (2006). The combined use of chemical and organic fertilizers and/or bio-fertilizer for crop growth and soil fertility, International Workshop on Sustained Management of the Soil-Rhizosphere System for Efficient Crop Production and Fertilizer Use, 16-20 October, Thailand., 11pp.

El-Ashry, M. Soad and M.A. El-Kholy. (2005). Response of wheat cultivars to chemical desiccants under water stress conditions. J. Appl. Sci. Res. 1 (2): 253-262.

Fischer, R. A. and R. Maurer. (1978). Drought resistance in spring wheat cultivars. I. Grain yield responses in spring. Australian Journal of Agricultural Research 29 (5): 897-912.

Gardner, F. P., R. B. Pearce and R. L. Mitchell. (1985). Physiology of Crop Plants. P. 202. Iowa State Univ. Press, Ames, Iowa, USA.

Garg, G. (2010). Response in germination and seedling growth in Phaseolus mungo under salt and drought stress. J. Environ. Biol. 31: 261264.

Gomez, K.A and A.A. Gomez. (1984). Statistical Procedures for Agricultural Research. John Wiley \& Sons, New York, USA.
Kamyar, K and E.Hamdollah. (2012). Does priming improve seed performance under salt and drought stress. J. Basic. Appl. Sci. Res. 2 (4) 3503-3507.

Karimizadeh, R., M. Mohammadi, S. Ghaffaripour, F. Karimpour and M. K. Shefazadeh. (2013). Evaluation of physiological screening techniques for drought-resistant breeding of durum wheat genotypes in Iran. Afri. J. Biotechnology 10:12107-12117.

Keyvan, S. (2010). The effects of drought stress on yield, relative water content, proline, soluble carbohydrates and chlorophyll of bread wheat cultivars. J. Animal \& Plant Sci. 8: 1051- 1060.

Khayatnezhad, M., R. Gholamin, Sh. Jamaati-eSomarin and R. Zabihi-e-Mahmoodabad. (2011). Scrutiny of hexaploid and tetraploid (Triticum durum) wheat's genotypes to some physiological responses in drought stress. Middle-East J. of Scientific Res. 7 (1): 12-16.

Mir, R.R., M. Zaman-Allah, N. Sreenivasulu, R. Trethowan and R.K. Varshney. (2012). Integrated genomics, physiology and breeding approaches for improving drought tolerance in crops. Theoretical and Applied Genetics 125: 625-645.

Mohammadi, M., R. Karimizadeh, M.K. Shefazadeh and B. Sadeghzadeh. (2011). Statistical analysis of durum wheat yield under semi-warm dryland condition. Aust. J. Crop Sci. 5:1292-1297.

Nayyar, H. (2003). Variation in osmoregulation in differentially drought-sensitive wheat genotypes involves calcium. Biologia Plautarum. 47(4): 541-547.

Raza, M. A. S., M. F. Saleem, G. M. Shah, M.Jamil and I. H. Khan. (2013). Potassium applied under drought improves physiological and nutrient uptake performances of wheat (Triticum aestivum L.). J. Soil Sci.and Plant Nut. 13:175-185.

Raza, M. A. S., M. F. Saleem; M. Y. Ashraf, A. Ali and H. N. Asghar. (2012). Glycine betaine applied under drought improved the physiological efficiency of wheat (Triticum aestivum L.) plant. Soil and Environment 31: 67-71.

Sharma, S., A. Gupta and J. Shekhar. (2010). Growth parameters in late-sown rainfed wheat as influenced by seed priming and foliar applied growth regulators. J. Res. SKUAST1: 63-69.

Siddiqui, MH., MH. Al-Whaibi and MO. Basalah. (2011). Interactive effect of calcium and gibberellin on nickel tolerance in relation to antioxidant systems in (Triticum aestivum L.) Protoplasma 248: 503-511.

Smith, J.A.C. and H. Griffiths. (1993). Plant Responses from cell to maturity. In: Water Deficits. Bios. Sci. Publishers Limited, India, pp: 1-4. 
Song, W. Y.; Z. Zheng-Bin, H. B. Shao, Z. L. Guo, H. X. Cao, H. B. Zhao, Z. Y. Fu and X. J. Hu. (2008). Relationship between calcium decoding elements and plant abiotic-stress resistance. Int. J. Biol. Sci. 4: 116-125.

Taylor, A. G and G. E. Harman. (1990). Concepts and technologies of selected seed treatments. Ann. Rev. Phytopathol. 28: 321-339.
Wang, X. and B. Shen. (1991). Effect of METsoaked seed on drought resistance of rice seedlings. Acta Phytophysiol Sin. 17: 105-108 (in Chinese with English abstract).

Zhang, L. X.; S. X. Li and Z. S. Liang. (2009). Differential plant growth and osmotic effects of two maize (Zea mays L.) cultivars to exogenous glycine betaine application under drought stress. Plant Growth Regulation 58: 297-305.

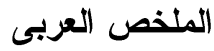 \\ تأثير نقع البذور والتسميد الحيوى والرش بالبوتاسيوم على تحمل أصناف القـح الصلب للجفاف فى مرحلة طرد السنابل}

عثمان السلهاب'، سامى شعبان الطباخ'، على عيسى نوار'، مسعد محمد الجنبيهى'، أحمد محجوب شعلان ' ألعان

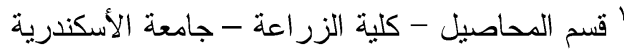

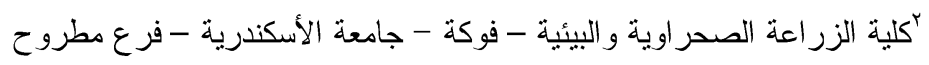

أجريت الدراسة لمعرفة تأثير عدة معاملات على تحمل ثلاثة أصناف من القمح الصلب للجفاف بعد مرحلة طرد

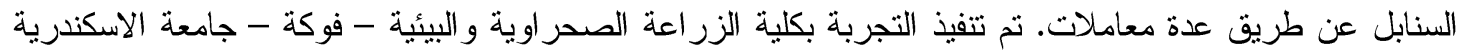

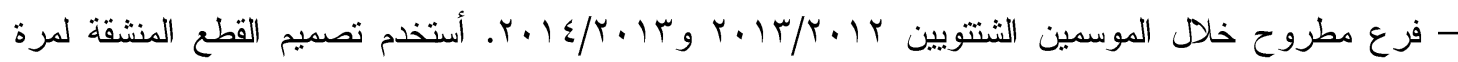

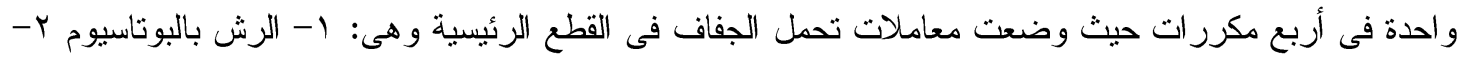

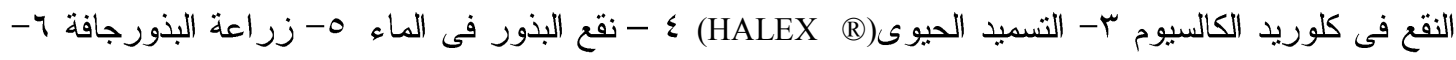
الرى الى نهاية الموسم (تم تعريض النبات فى المعاملات الخمس الى الأجهاد بوقف الرئ بألى بعد مرحلة طرد السنابل).

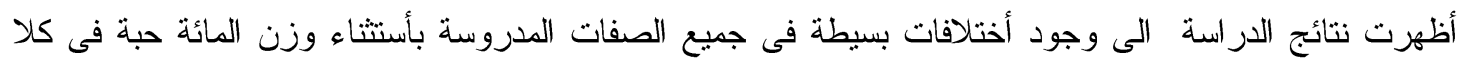

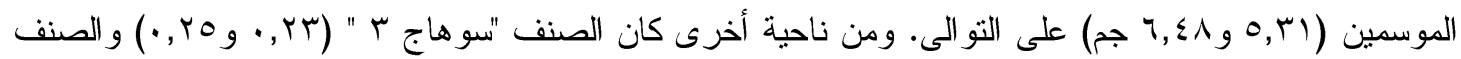

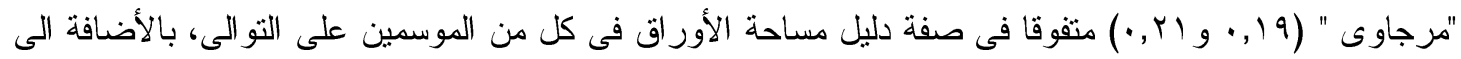

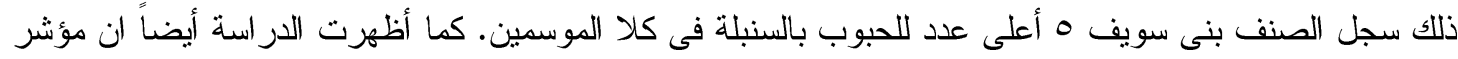

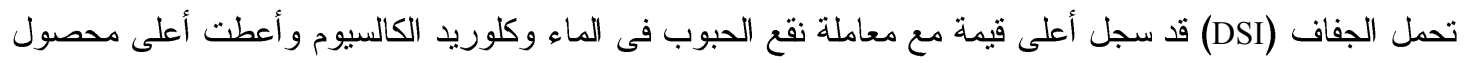

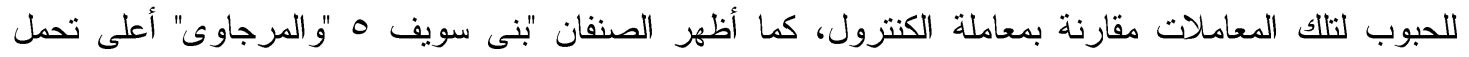
للجفاف مقارنة بالصنف "سو هاج ب"ا. 